the œsophagus respectively. From these the carotid and subclavian vessels with their nerves derive sheaths, so the air now runs along these structures into the limbs and neck."

With regard to the explanation that in these cases the condition arises owing to the air obtaining an entry through lesions of the upper air passages, such as injuries to the lips, I would ask-tor information-if such emphysema would become so extensive as in the case $I$ have recorded. Moreover, bearing in mind with what frequency such injuries are met with during labour and in how many other cases they are possibly overlooked, ought not cases of emphysema during parturition to be much more common? In my case no lesions of the lips or mouth were observed nor was my attention drawn to any by the patient subsequently, and given such lesions would excessive efforts at expiration with the glottis closed produce the emphysema?

I am, Sirs, yours faithfully.

Gloucester, Nov. 5th, 1905. Francis H. SPRAgute.

\section{THE ESSENTIAL CONDITIONS OF STEAM DISINFECTION.}

To the Haitors of THE LANCET.

SIRS, - I have read with great interest the correspondence that has been going on in your pages between Dr. J. C. Thresh and Mr. Wolf Defries. Allow me therefore to join in the discussion. The subject of steam disinfection is not only of paramount interest to the sanitarian but also to the surgeon, since the latter must be anxious to know which is the better, more thorough, and scientific agent for the effective sterilisation of dressings, \&c.-steam under pressure or steam generated and given off at atmospheric pressure. And while the latter has come to be known as "current" steam, it has no exclusive right to that nomenclature, because pressure steam when passed through a disinfecting chamber in a "current" is a most powerful germicide by reason of its great penetrative powers.

Dr. Thresh and Mr. Defries are at variance with reference to the one important point: Is pressure or non-pressure steam the more reliable agent for disinfection? The whole subject is most engrossing and it is one in which $I$ bave taken a very keen and, I might add, practical interest. When I began about eight years ago to experiment with a steam disinfector I was an implicit believer in the virtues of nonpressure (current) steam. I had not the opportunity to go deeply into the question at that time on account of translation to my present sphere of labours. Still a devotee to nonpressure steam I devised, along with a fellow medical officer of health, a steam disinfector. This we intended to announce as a rapid acting non-pressure (current) steam disinfector. Koch's dogmatic assertion regarding the superiority of nonpressure over pressure steam had converted me to his view. But experiments repeated time and again have proved to me without the shadow of doubt that my faith in non-pressure steam was unjustified. And from that time I have been an implicit believer in the superiority of pressure steam. Moreover, when one hears that non-pressure disinfectors at certain altitudes above the sea level cannot raise the temperature inside the disinfecting chamber to boiling point one begins to harbour additional misgivings. Up to a certain stage my experiments with non-pressure steam were fairly satisfactory. It must be emphasised that I was provided with a form of boiler capable of generating great volumes of steam, which were forcibly propelled through the disinfecting chamber at a velocity far in excess of that possible with the type of generator attached to the nonpressure apparatus in present-day use. This question of velocity in non-pressure disinfectors is a most material one and has been duly emphasised by Professor S. Delépine of Manchester. In a word, I gave non-pressure steam the very best opportunities it ever had to display its supposed powers of quick penetration. When called upon to penetrate blankets light]y folded upon themselves nonpressure (current) steam did its work efficiently as compared with pressure steam. But I must repeat the statement already made that $I$ was forcibly propelling steam through the chamber. In ordinary circumstances steam in a nonpressure machine simply flows from end to end of the chamber. When I came to deal with flock mattresses folded upon themselves non-pressure steam was, to put it colloquially, "out of the running" with its rival pressure steam.

At this point let me add a most important reservation in order to clear away any ambiguity as to the proper use of pressure stream in connexion with a disinfecting chamber of any kind. Pressure steam may be employed for an indefinite length of time in fruitless attempts to kill micro-organisms inside a sealed chamber, if the air in that ohamber has not been in the first instance driven ont. This I have proved over and over again, not in a miniature apparatus but in a chamber 7 feet long and 3 feet 6 inches in diameter. Koch's house of cards as to the superiority of nonpressure (current) steam over pressure steam collapses over this very point. Koch declared in favour of nonpressure steam because he had not given pressure steam the opportunity to show its paces. He actually hampered pressure steam by requiring it to act in the presence of air left in the chamber. Yet that inaccurate observation-I think the adjective can be legitimately usedhas laid the foundation of a mistaken faith in non-pressure steam. This point is one that deserves the very serious consideration of all surgeons who treat their dressings in pressure apparatus. As will be presently shown, to attempt to sterilise dressings without first discharging or expelling the air contents of the steriliser is to court grave risk of inefficiency. It was one of the most interesting points in my experiments to watch this phenomenon of air expulsion. When the doors of the disinfecting chamber were closed and steam turned on, the air, being expelled before the incoming steam, blew out one lighted match after the other. In the course of three minutes a faint cloud of warmish vapour appeared at the outlet. Finally, at the end of five minutes, when the chamber had been filled, steam came in full blast from the outlet. I have detailed these facts to demonstrate that for fully three minutes nothing but air issued from the chamber. Had that air been permitted to remain in the chamber it would have acted as a most effectual " buffer" to the steam as a disinfecting agent. In the presence of air, as has already been said, steam is a feeble disinfectant because air is a wretched heat conductor. Current (non-pressure) steam has shown an apparent superiority over pressure steam because the current pushed all air before it. Not until continental observers-and $I$ must not forget Mr. Defries in this country-pointed to the absolute necessity for air expulsion in pressure apparatus did the superiority of pressure over non-pressure steam come to be understood and appreciated. As a result of my experiments nothing will now convince me that non-pressure steam can penetrate as efficiently and rapidly as pressure steam and that notwithstanding the powerful aid of a steam pump. Let me quote some of the experiments performed at a time when my mind was biased in favour of non-pressure (current) steam. The chamber in which the following tests were made was of 70 cubic feet capacity. It would be interesting to know the dimensions of the chamber in which tests of non-pressure apparatus were made, since the smaller the chamber the more rapid the flow of steam through it and the more favourable the conditions for nonpressure steam.

1. Non-pressure (current) steam. Anthrax spores were placed between the folds of a mattress folded upon itself and laid in the wire cage of the disinfecting chamber. Beside the spores was placed a thermometer set to ring an electric bell at $212^{\circ} \mathrm{F} .\left(100^{\circ} \mathrm{C}\right.$.). I give the actual times from my notes. From 2.36 till 2.41 steam was driven through the chamber to expel all air. At 3.1 the bell rang. At 3.21 steam was turned off and the chamber opened. The resulting test of the threads showed typical growth of anthrax on agar and in broth. It will be observed that 20 minutes elapsed ere the bell rang and that the spores were submitted to steam at $212^{\circ} \mathrm{F}$. for 20 minutes with absolutely negative results. I need only to refer to Globig's experiments in support of this experiment of mine. He was unable to kill anthrax spores after exposing them to non-pressure steam for five and six hours. My own experiment was at a subsequent date verified by Dr. Buchanan of the Usher Institute.

2. Now let us turn to the pressure steam result. As before, the spores and thermometer were placed inside a mattress folded upon it:elf. Air was expelled from 1.57 till 2.2, when the exit was closed. At 2.7 the bell rang violently, the pressure in the chamber indicating 10 pounds on the gauge. At 2.9 the pressure had risen to 15 pounds, after which a current of steam was permitted till 2.19 The result was that at the end of ten days there was no growth of anthrax in any shape or form. In the former case 20 minutes elapsed ere the bell rang. With pressure steam, 
on the other hand, the beil rang in five minutes. The effect of pressure steam on the vitality of the resistant spores is patent to everyone. Globig was able to kill anthrax spores in ten minutes. It was my desire to place the two varieties of steam on an equal footing with, as has been proved, disastrous results to the non-pressure rival. So much for Koch's postulate.

Lastly, let me give a graphic illustration to indicate where the fallacy has arisen as to the relative merits of pressure and non-pressure steam.

3. A thermometer to ring a bell at $212^{\circ} \mathrm{F}$. $\left(100^{\circ} \mathrm{C}\right.$.) was placed inside 16 folds of blanket and a current of nonpressure steam turned on at 2 P.M. At 2.9 the bell rang vigorously. Now let us observe the following result.

4. The thermometer was again placed within 16 folds of blanket (not the blanket heated by the former test) and steam admitted to the chamber and confined there. That is to say, there was no attempt made to get rid of the contained air. At the end of ten minutes, though the pressure of steam inside the chamber indicated 15 pounds, the bell remained quiescent. The pump was working vigorously and to avoid accidents to the chamber it was necessary to cut off steam or allow it to escape from the chamber. 'The latter precaution would have allowed a current of steam to flow through the chamber and air would have been expelled. This procedure would have defeated the end I had in view-namely, to prove that in the presence of air locked up inside the chamber even steam at a pressure of 15 pounds was incapable of penetrating an object readily searched through and through by non-pressure (current) steam. I can scarcely conceive anything more convincing. It is one thing to deal with steam confined under pressure, as this last experiment showed, but quite another to speak of steam confined under pressure, air having first been expelled. The whole science and art of true steam disinfection lies hidden in that statement. The one method is as inefficient as the other is certain in its action.

Dr. Thresh is inclined to draw a red herring across this controversy. He desires to point out that after all the infections with which a disinfector has to deal are caused by organisms that are easily killed. That is not the point, however. If non-pressure steam cannot penetrate, as I have proved it cannot penetrate, such objects as mattresses as well as pressure steam can, then it cannot be held to be as effectual a weapon in the hands of the sanitarian. Nay, more, we are aiming at standards nowadays, and before long we may arrive at a common understanding with regard to disinfectants. Why, then, should steam disinfectors not be the possessors of a standard of real efficiency?

I can safely say that never did non-pressure (current) steam receive a better opportunity to display its powers than was afforded it during my experiments. It came out of the ordeal a poor second. Let me conclude my rather lengthy communication with a suggestive observation. During my earlier experiments, some years ago, I enlisted the valued and kindly assistance of that eminent authority in bacteriology, Profiessor Robert Muir of the University of Glasgow. He prepared the test threads for me and undertook to examine them after they had been subjected to steam. My joy was great when a week after making my tests he wrote informing me that my results were apparently successful. The organisms had been killed. At the end of another three days, however, he declared that on looking at the tubes again he found that in one or two instances anthrax showed faint growth, as did bacillus subtilis. This point is a most significant one and impresses one with the necessity for displaying extreme care in the announcement of results.

I am really sorry to have trespassed so much upon your space but the subject is one that merits discussion. Far too much has been taken for granted in the past with regard to what steam can do under varying conditions, especially in the direction of disinfection and sterilisation. My own experience is a case in point.

$$
\text { I am, Sirs, yours faithfully, }
$$

Leith, Nov. 7th, 1905

$$
\text { WM. Robertson, M.D. Glasg., D.P.H., }
$$

\section{ADFENALIN IN THE TREATMENT OF HÆMOPTYSIS.}

To the Editors of THE LANCET.

SIRS,--In reference to a note in a recentisetter from your Paris correspondent and to an annotation thereon with the above title, may I say that I used adrenalin by direct intratracheal injection over two years ago. The patient, who was sent for treatment (for phthisis) by Mr. H. Ruskin Hancock of Leicester, had had one or two previous attacks and was much alarmed at its recurrence. I administered 40 minims of a 1 in 1000 solution in one and a half drachms of water three times at intervals of eight hours ; the first dose checked the hæmorrhage immediately and it did not recur. I am, Sirs, yours faithfully,

Southport, Nov. 5th, 1905 .

Colin Campbell.

\section{THE INTERNATIONAL CONGRESS ON TUBERCULOSIS AT PARIS.}

(From our SPECIAL CorRespondent.)

\author{
THE SECTIONS. \\ Friday, OCt. 6Th. \\ FoURTH SECTION.
}

Tuberculosis and the Housing Question.

UNHEALTHY dwellings as a prominent cause of tuberculosis had already and frequently been denounced in the section, but now those present were called upon to discuss. in detail this phase of the question. A report was presented by M. PaUl Juillerat, chief of the Paris sanitary office established to watch over domestic sanitation and to draw up the sanitary record of individual houses. Just as the police keep a criminal record of individuals, so does this department keep a record, it might almost be called a criminal record, of the preventable deaths that have occurred in the different houses. Thus is a sanitary history being gradually built up of each dwelling. In regard to tuberculosis this history conveys a more emphatic teaching than with respect to most of the other diseases, particularly as the observations now date back for some time, including the period when they were first organised by M. Louis Masson. The technical term used is "Le Casier Sanitaire des Maisons." That is the draw, case, or portfolio in which records are separately kept. Now judging by the record of the 11 years from 1894 to 1904 the mortality from tuberculosis at Paris differs according to the height of the apartment or tenement inhabited. Excepting the top, or garret floor, inhabited by servants and very poor people, the lower the floor the greater the mortality. In six bad areas comprising 1584 houses, inhabited by 59,081 persons, only 416 houses were free from the disease during the 11 years. All the other transmissible maladies caused a mortality of 1.81 per 1000 of the population; the mortality from tuberculosis in these areas was $8 \cdot 25$ per 1000 . During the 11 years 101,496 deaths from pulmonary tuberculosis occurred in 39.477 houses. Of these houses 5265 were inhabited by 426,676 people and 38,009 of them died, but of these deaths 11,500 occurred in only 820 houses, which, however, had a population of 106,300 . Thus it will be seen that tuberculosis is localised. There are certain dwellings where it is always present. It has also been noticed, and this is very important, that these contaminated buildings affect fatally other houses in their immediate neighbourhood, th ough these latter do not present the same serious sanitary defect:. The sanitary defects were all alike : narrow streets, narrow courts, no air, and no direct sunlight, and the reporter concluded that tuberculosis was essentixlly "a disease of obscurity." Then two plans were submitted. One an area to the eas $t$ of the Boulevard Sebastopol included the celebrated slum street, the rue de Venise and the historic rue Quincampoix, where John Law carried out those financial sp'culations which were to France what the South Sea Bubble was to England. In this area 70 per cent. of the ground is covered with buildings. There are 281 houses with 9715 inhabitants, and in only 30 of these houses bave there been no deaths from tuberculosis during the 11 years. The general annual death-rate in some of these houses is equal to 42.63 per 1000 and the deaths from tuberculosis alone are equal to $124 \cdot 50$ per 10,000 . The other plan comprises an area in the Quartier de l'Europe, a little above the Gare St. Lazare. Here 54 per cent. of the area is built over. There are 191 houses, with 5705 inhabitants; deaths from tuberculosis have occurred in 75 of these houses and the deatlu-rate from this cause is equal to $11 \cdot 90$ per 10,000 annually. Thus in the one district the deaths from tuberculosis are ten times more frequent than in the other. The kitchens are denounced as the chief culture ground for Koch's bacilli. Here there is little or no ventilation, with 